\title{
A study on powerloom business in some selected areas of Sirajganj district: It focuses on present scenario and future prospect
}

\author{
Airin Rahman ${ }^{1}$, Abu Zafar Ahmed Mukul², Sauda Afrin Anny 3, * \\ ${ }^{1}$ Department of Agribusiness \& Marketing, Sher-e-Bangla Agricultural University (SAU) Dhaka-1207, Bangladesh \\ ${ }^{2}$ Department of Management \& Finance, Sher-e-Bangla Agricultural University (SAU) Dhaka-1207, Bangladesh \\ ${ }^{3}$ Faculty of Agribusiness Management, Sher-e-Bangla Agricultural University (SAU) Dhaka-1207, Bangladesh

\section{Email address:} \\ airin_sau007@yahoo.com(A. Rahman),mukul_mgt@yahoo.com (A. Z. A. Mukul), anny3543@gmail.com (S. A. Anny)
}

\section{To cite this article:}

Airin Rahman, Abu Zafar Ahmed Mukul, Sauda Afrin Anny. A Study on Powerloom Business in Some Selected Areas of Sirajganj District: It focuses on Present Scenario and Future Prospect. International Journal of Business and Economics Research.

Vol. 3, No. 4, 2014, pp. 140-149. doi: 10.11648/j.ijber.20140304.11

\begin{abstract}
The powerloom industry as a tool of Small and Medium Enterprise (SME) has a greatest possibility to contribute a lot in the cloth production of Bangladesh. In this paper authors try to represent the overall socio-economic status of businessmen who are engaged in powerloom business in some selected area of Sirajgonj district. Authors have identified those prominent factors that are moving the wheels of this industry slowly. Among them, shortage of working capital, high cost of raw materials, inadequate supply of electricity, lack of policy support are bitterly hit the powerloom industry. Besides these, authors also try to identify the future prospects of powerloom business in their research area.
\end{abstract}

Keywords: Powerloom Business, Social Status, Economic Development, Future Prospects

\section{Introduction}

The powerloom industry is one of the weaving hubs of the country an important segment of the decentralized cotton textile industry in Bangladesh. Powerloom industry weaves cotton by power-operated machines or looms and works into a fabric with the help of warp in the form of beam and weft directly through bobbins. Sirajganj district is famous for independent weaving units for a long time. Belkuchi, Shahzadpur, Chowhali, Ullapara, Kamarkhanda, Sirajganj Sadar, Kazipur and Raiganj Upazilas are mostly dominated by weaving factories. The study is concerned with only the powerlooms which are in small-scale sector of Bangladesh and this sector is one of the most important segments of the textile industry in terms of fabric production and employment generation. According to Bangladesh Tant Board officials, there are about two lakh weaving factories in these eight upazilas. Of them, about 1.35 lakh are handlooms while the rest are powerlooms. About three lakh people work in the handloom factories, while about one lakh work in the powerloom units. About 15 lakh people, directly and indirectly, are dependent on the weaving industry. Weavers in Sirajganj mainly devote themselves to weaving saris, lungis and gaamchhas (locally made towels). These products are supplied to different parts of the district and also exported to Saudi Arabia, Kuwait, Qatar, Burma, Malaysia and Germany. Present study is concerned with the socio economic status and development of businessmen engaged in small and medium scale powerloom sector of some selected areas of Sirajgonj district of Bangladesh. One basic limitation of the study is the lack of availability of sufficient data.The data was as current and accurate as possible. There is no authentic and huge numbers of literatures about this area but some literature are there, which are helpful for the study and research purposes. The handloom sector is the largest traditional cottage industry in Bangladesh. It provides employment for more than 888115 people and is the second largest employment provider after agriculture (BBS 2005). Handloom products have shown decisive upward trend in the export market since 1972 and Bangladeshi handloom products with their distinctive design and superior quality have created a niche for themselves in overseas markets. It can now proudly be claimed to be equipped to meet the demand for the latest fashion. An international expert's study reveals that the technical skill of weavers of Bangladesh is 
second to none in the handloom producing world (The Bangladesh Observer, 2004). The sector has a prospect for labour intensive and capital saving growth. Handloom weaving can reduce unemployment and underemployment of rural households. Concerning the handloom industry, a few studies (Chowdhury, 1989; Latif, 1988) indicated the overall growth of handloom industries and efficiency between handloom and powerloom weaving. In this context data and information interms of capacity, output, technological upgradation, product specialization and modernization are all the important to look at. In Bangladesh, it was found that 10 largest cloth producing districts namely Sirajgang (31.8\%), Tangail (10.9\%), Narayanganj (10\%), Pabna (9.8\%), Narshingdi (9\%), Kustia (6.5\%), Bogra (3.2\%), Dhaka (2.3\%), Brahmanbaria (2.3\%) and Satkhira (1.6\%) account for about $87.3 \%$ of total monthly cloth production in the handloom industry (BBS 2005). Within Sirajganj district there were approximately 14870 handlooms weaving families and 100757 year round working handlooms (BBS 2005). Handloom industry of Sirajganj faced with manifold problems since long because of increase in price of yarn and dye, lack of government loan facilities and unavailability of quality chemical dying. A new handloom product has been developed by Grameen Bank- a leading non-government rural oriented financial institution with trade name "Grameen Check" which is soft, colour fast and $100 \%$ cotton. The "Grameen Check" fabric and the apparels made out of it have already made a breakthrough in European markets with potential of penetrating other parts of the world. Sirajganj district earned a name for quality handloom products such as Grameen check, Aarong check, lungi, dhuti, bed sheets and saris. Handloom industryof Sirajganj district is account for more than $31 \%$ of the total handloom production of the country (BBS 2005). Due to shortage of investment, a large number of looms were closed in the last two decades. Many skilled weavers left the occupation. The government introduced loan disbursement programme in 1984 to restore the handloom sector. Loans of Tk. 5,500 for each semiautomatic handloom and Tk. 3,500 per handloom were distributed in cooperation with Bangladesh Handloom Board But soon after the disbursement of loans, it was found that a big amount of total money was given to the fake weavers. In view of the fact the programme remained suspended (Internet Edition, HOLIDAY, 2003). In 1949 M.M. Mahta studied the trends in size of cotton spinning and weaving units at different clusters like Bombay (Mumbai), Ahmedabad, Madras (Chennai) and other important clusters of the country for the period of 1905 to 1944 . He emphasised on the size of the industrial units in weaving industry. S.V. Chorghade (1976) in his research work studied the "Powerloom Industry In Maharashtra". Maharashtra state has a lion's share in the growth and development of the Powerloom industry. He attempted to undertake a detailed study of structure and problems of Powerloom industry in Maharashtra. P.R. Ojha (1978) studied the dividend distribution of 51 cotton textiles companies. He analysed the dividend distribution of the companies on the basis of size, region, ownership group, management pattern and age of the companies. R. R. Ansari (1984) in his research work explained the marketing problems of Powerloom industry in Malegaon City of Nashik District. He has very specifically indicated the marketing problems faced by the Powerloom industry. Omkar Goswami (1985) has made an analysis of demand and supply in the cotton textile industry. According to him, only the Powerloom sector and the pure spinning units seem to be doing well. Sixty five to seventy percent of composite mills and the entire handloom sector are sick. $V$. $S$. Mangnale (1987), in his research work about labour absenteeism in Textile Industry in Solapur, attempted to identify the causes of labour absenteeism in textile town of Solapur. He studied the nature of absenteeism and highlights the different dimensions of the problem. B.M. Dolle (1992) in his research work revealed the socio - economic problems of powerloom industry in Malegaon. He studied the powerloom industry of Malegaon for the period of 1935 to 1985. The main conclusions of the study are; the powerloom industry in Malegaon has seen many ups and downs in its development and it is one of the important industries of Maharashtra. The powerloom industry in Malegaon has glorious past and bright future. There are many socio economic problems in the powerloom industry of Malegaon like scarcity of the finance, marketing problems, labour problems etc. D. C. Mathur in his book "Personnel Problems and Labour Welfare A study of cotton textile industry (1993)" had explained about personnel management in the cotton textile industry. He explained that for the economic results the management of personnel is very important. B. Sabhoo (1993) in his research work he explained the problems and prospects of textile industry with special reference on the productivity of large and small scale textile industries. He attempted to throw light on the factor productivity of the textile industry.

\section{Objectives of the Study}

$>$ To know the social status of businessmen.

$>$ To know the economic development of businessmen after doing business.

$>\quad$ To find out the constraints of doing business.

$>$ To identify the prospect of business in the locality.

\section{Research Methodology}

\subsection{Research Method}

Methods followed to conduct the research were-

- $\quad$ Sample survey (Random sampling method)

- Observation

\subsection{Research Area}

Following areas of Sirajgonj district were selected as research areas considering security, easy access and other facilities-Tamai, Bekuchi, Khukni, Batil, Boura, Sernogor, Sohagpur, enayetpur villages of Sirajgonj district. 


\subsection{Population and Sample Size}

Businessmen of Power loom industry of abovementioned areas. The businessmen were selected on the basis of their availability during interviewing time as sample. Survey with 30 entrepreneurs, the selected entrepreneurs had different amount of investment and machines ranges from small scale to medium scale.

\subsection{Techniques of Data Collection}

Relevant information were collected by direct interview, using a pre-tested schedule and by general observation. Close ended questions were used in the schedule.

\subsection{Data Processing, Analyzing and Presentation}

Synthesize and analyze all the data as inputs for designing a framework for analysis. Each of the information have documented and finally analyzed synthesized to make them meaningful.. For presentation, Microsoft Office (MS Word and Excel) were used.

\subsection{Data Collection Period}

Mid July to first week of August of year 2013.

\section{Limitations}

The limitations, faced during conducting the research were:

$>$ Due to lack of idea about research or project among the businessmen, the investigators encountered some difficulties to approach the interviewees. The survey result would be more representative if all the camps could be covered.

$>$ Some of the respondents were found a bit reluctant to give answers to the research questions. They informed that such types of research were done in the past without any benefit to them.

$>$ Sometimes it was hard for the respondents to manage time to give in-depth interviews.

$>$ Frequent power failure disrupted data processing and preparation of report.

\section{Personal Information of Respondents}

\subsection{Age}

Table 1. Age of respondents (Businessmen)

\begin{tabular}{lll}
\hline Age of businessmen(in year) & Frequency & Percentage \\
\hline $21-30$ & 9 & 30 \\
$31-40$ & 8 & 26.67 \\
$41-50$ & 6 & 20 \\
$51-60$ & 5 & 16.67 \\
Above 60 & 2 & 6.67 \\
Total & 30 & 100 \\
\hline
\end{tabular}

Source: Primary Data From Field Survey.
In my total sample, there were 30 respondents. Among them 30 percent of sample age is between 21-30 years. 26.67 percent is above 31 years and below 40 years. 20 percent respondents age lies between 41-50 years and 16.67 percent is above 51-60 years old, and 6.67 percent is above the age 60 years.

\subsection{Education}

Among my selected sample 36.67 percent businessmen had primary education, 36.67 percent had educational level of SSC, 20 percent had HSC and 6.67 percent had graduation.

Table 2. Education of the respondents (Businessmen)

\begin{tabular}{lll}
\hline Education level & Frequency & Percentage \\
\hline Illiterate & 0 & 0 \\
Primary education & 11 & 36.67 \\
SSC & 11 & 36.67 \\
HSC & 6 & 20 \\
Graduation & 2 & 6.67 \\
Total & 30 & 100 \\
\hline
\end{tabular}

Source: Primary Data From Field Survey.

\subsection{Reasons for Choice of Profession}

Table 3. Reasons of their choice of the profession

\begin{tabular}{lll}
\hline Reasons & Frequency & Percentage \\
\hline Family tradition & 12 & 40 \\
No scope of other profession & 2 & 6.67 \\
Personal likings & 6 & 20 \\
Sufficient income in the past & 10 & 33.33 \\
Total & 30 & 100 \\
\hline
\end{tabular}

Source: Primary Data From Field Survey.

Majority (40\%) of the respondents selected this profession because of their family tradition. For many years the people of this locality engaged in handloom business and now transferring to powerloom business. 33.33 percent people are engaged in this business, because they had sufficient income in the past from doing this business. 20 percent people do this business because of their personal likings and 6.67 percent people do this business because they had no scope of other profession.

\subsection{Selling Capacity of Respondents}

Table 4. Number of pieces of Lungi's is being sold per week.

\begin{tabular}{lll}
\hline Number of Lungi sold (per week) & Frequency & Percentage \\
\hline $500-1500$ & 12 & 40 \\
Above 1500-2500 & 12 & 40 \\
Above 2500-3500 & 2 & 6.67 \\
Above 3500-4500 & 1 & 3.33 \\
Above 4500 & 3 & 10 \\
Total & 30 & 100 \\
\hline
\end{tabular}

Source: Primary Data From Field Survey. 
Number of Lungi sold per weeks varies from 500-1500 and above 1500-2500 pieces for $40 \%$ respondents. $6.67 \%$ businessmen sold above 2500-3500 Lungi per week, $3.33 \%$ people sold above 3500-4500 Lungi per week and $10 \%$ businessmen sold above 4500 Lungi per week. Production depends mostly on number of looms owned by the entrepreneurs. For instance, the entrepreneurs producing above 500 Lungi per day owns $50-60$ powerlooms.

\subsection{Present Income of Entrepreneur (with and Without Marketing Outlet)}

Businessmen of the locality sell their products either directly to their customers or sell their products to different company on a contract basis. When they go for direct selling to the customers in the hat or market they get higher profit and their level of income increase.

Table 5. Present income of Entrepreneur (with and without marketing outlet)

\begin{tabular}{llll}
\hline $\begin{array}{l}\text { Entrepreneur (without } \\
\text { marketing outlet) }\end{array}$ & $\begin{array}{l}\text { Entrepreneur (with marketing } \\
\text { outlet) }\end{array}$ \\
\hline $\begin{array}{l}\text { Income range (per } \\
\text { month in BDT) }\end{array}$ & Frequency & $\begin{array}{l}\text { Income range (per } \\
\text { month in BDT) }\end{array}$ & $\begin{array}{l}\text { Frequenc } \\
\text { y }\end{array}$ \\
\hline $25000-35000$ & 3 & $25000-35000$ & 1 \\
$36000-45000$ & 8 & $36000-45000$ & 5 \\
$46000-55000$ & 8 & $46000-55000$ & 10 \\
$56000-65000$ & 4 & $56000-65000$ & 5 \\
$660000-75000$ & 3 & $660000-75000$ & 4 \\
Above 76000 & 4 & Above 76000 & 5 \\
\hline Total & 30 & Total & 30 \\
\hline
\end{tabular}

Source: Primary Data From Field Survey.

From table 5 it can be seen that when businessmen have marketing outlet they earn more money than when they sell their product without any marketing outlet. Frequency of high income range increase when entrepreneurs have marketing outlet.

\section{Business Information's}

\subsection{Information about Raw Materials}

The raw materials of Powerloom are imported from foreign countries like China, Japan, Korea, Vietnam, India, Taiwan and Pakistan through different agencies with 25 percent import duty, which is then sold to the local markets. The entrepreneurs have to buy the raw materials from local market at a very high rate. As a result production cost increases. But the supply of raw materials is sufficient, they opined. Most of the businessmen buy their products from the local market. Some big businessmen also buy their products from Narayangonj.
Table 6. Preferences of yarn imported from various countries

\begin{tabular}{ll}
\hline Proffered countries & Percentage \\
\hline China & 61 \\
Japan & 13 \\
Vietnam & 11 \\
India and others & 15 \\
Total & 100 \\
\hline
\end{tabular}

Source: Primary Data From Field Survey.

Majority of the respondents said that quality of yarn from China is good where as rest prefers yarn imported from Japan, Vietnam, Korea, India, Pakistan, and Taiwan etc.

\subsection{About Design}

The sources of their designs they informed are

a) Self-invented-50 percent

b) Indian Catalogue: 50 percent

They do not have any institutional training. So they put great emphasis for the need of technical and professional training.

\subsection{The Sources of Capital of the Entrepreneurs are}

Table 7. Source of capital of the entrepreneurs

\begin{tabular}{ll}
\hline Source of capital & Percentage \\
\hline Bank loan & 30 \\
Self-savings & 65 \\
Local people & 5 \\
\hline
\end{tabular}

Source: Primary Data From Field Survey.

Out of total capital invested $30 \%$ is loan from various sources. The workers produce mostly Lungi. Some of them also produce Saree, Salowar kamiz, Duti etc. They can produce near about double pieces of products if they get more technical and financial support. According to the entrepreneurs, the present production system is not profitable now as before because of high cost of production and low price of products

\subsection{Approximate Profit from a Product}

Table 8. Approximate profit of businessmen from production of a Lungi (without marketing outlet)

\begin{tabular}{ll}
\hline Cost types & Cost (TK) \\
\hline Yarn & 107 \\
Dying & 39 \\
Yarn Beam & 7 \\
Inner Shattel & 3 \\
Labour wages (weaver, deginer, auxiliury workers) & 59 \\
For Beam cover & 4 \\
Shana Bow & 1 \\
Others cost & 3 \\
Total Cost & 223 \\
Sale price & 235 \\
Profit & 12 \\
\hline
\end{tabular}

Source: Primary Data From Field Survey. 
Table 9. Approximate profit of businessmen from production of a Lungi (with marketing outlet)

\begin{tabular}{ll}
\hline Cost types & Cost (TK) \\
\hline Yarn & 107 \\
Dying & 39 \\
Yarn Beam & 7 \\
Inner Shattel & 3 \\
Labour wages (weaver, deginer, auxiliury workers) & 59 \\
For Beam cover & 4 \\
Shana Bow & 1 \\
Mercerize & 35 \\
Level & 1 \\
Poly & 1 \\
Others cost & 3 \\
Total cost & 260 \\
Sale price & 360 \\
Profit & 100 \\
\hline
\end{tabular}

Source: Primary Data From Field Survey.

\subsection{Market Information}

Majority of the entrepreneurs who do not have their own show room sell their products through the Various Lungi Company. Different large Lungi companies have branch in this locality. They buy Lungi from the local businessmen in a contract basis. Followings are some company name which have branch in the locality.

1. Amanot shah Lungi company.

2. Standard Company

3. Fozor Ali Lungi Company

4. Memory Lungi Company

5. Boshundhora Company

6. Pakija Lungi Company

7. Sensory Lungi Company

8. Bokhari Lungi Company

Besides these companies, there are some others company have branch in the district. Some businessmen go for direct selling and sell their products in the hat, bazer and in various showrooms of different cities and towns of the country. The rest sell their products to wholesalers of other areas of Dhaka city.

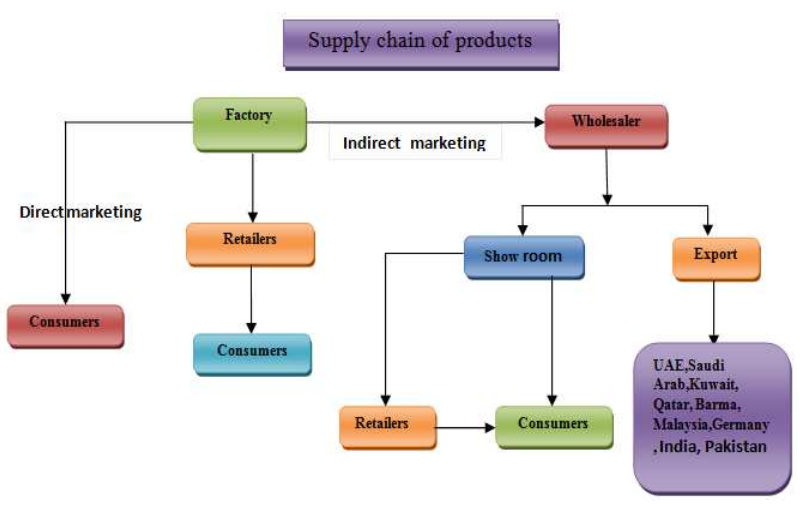

Diagram: Flow chart of marketing of product

\section{Key Findings of my Observation}

\subsection{Frequency Tables}

Table 10. Source of pure drinking water

\begin{tabular}{llllll}
\hline & Frequency & Percent & $\begin{array}{l}\text { Valid } \\
\text { Percent }\end{array}$ & $\begin{array}{l}\text { Cumulative } \\
\text { Percent }\end{array}$ \\
\hline Valid & $\begin{array}{l}\text { Tube } \\
\text { well }\end{array}$ & 30 & 100.0 & 100.0 & 100.0 \\
\hline
\end{tabular}

Source: Calculated From Primary Data

From the table 10 it can be seen that, all of the respondents have the accessibility to safe pure drinking water. $100 \%$ respondents collect their drinking water from safe source.

Table 11. Hygienic sanitation facility

\begin{tabular}{llllll}
\hline & & Frequency & Percent & $\begin{array}{l}\text { Valid } \\
\text { Percent }\end{array}$ & $\begin{array}{l}\text { Cumulative } \\
\text { Percent }\end{array}$ \\
\hline \multirow{2}{*}{ Ves } & 27 & 90.0 & 90.0 & 90.0 \\
& $\begin{array}{l}\text { No } \\
\text { Valid }\end{array}$ & 1 & 3.3 & 3.3 & 93.3 \\
& $\begin{array}{l}\text { No } \\
\text { comment }\end{array}$ & 2 & 6.7 & 6.7 & 100.0 \\
& Total & 30 & 100.0 & 100.0 & \\
\hline
\end{tabular}

Source: Calculated From Primary Data

From the above frequency table, we can see that $90 \%$ respondents have hygienic sanitation facility. About $7 \%$ respondents avoid the question to answer. And about only 3\% respondent has not hygienic sanitation facility.

Table 12. Educational status

\begin{tabular}{clccll}
\hline & Frequency & Percent & $\begin{array}{l}\text { Valid } \\
\text { Percent }\end{array}$ & $\begin{array}{l}\text { Cumulative } \\
\text { Percent }\end{array}$ \\
\hline \multirow{2}{*}{$\begin{array}{l}\text { Primary } \\
\text { education } \\
\begin{array}{l}\text { Secondary } \\
\text { education }\end{array}\end{array}$} & 11 & 36.7 & 36.7 & 36.7 \\
$\begin{array}{l}\text { Higher } \\
\text { secondary } \\
\text { education }\end{array}$ & 6 & 20.0 & 20.0 & 93.3 \\
\hline $\begin{array}{l}\text { Graduation } \\
\text { Total }\end{array}$ & 2 & 6.7 & 6.7 & 100.0 \\
\hline
\end{tabular}

Source: Calculated From Primary Data

From the above table it can be seen that, most of the businessmen has primary and secondary education, few businessmen has higher secondary education and very few person has education of graduation level. About 37\% people has primary education, $37 \%$ people has secondary education, 20\% people has higher secondary education and about $7 \%$ people has graduation. So, from above data it can be seen that, higher institutional education is not essential for doing this business, rather practical experience of doing business is more important for doing the business. 
Table 13. Type of house

\begin{tabular}{llllll}
\hline & & Frequency & Percent & Valid Percent & Cumulative Percent \\
\hline \multirow{4}{*}{ Valid } & Tin shed & 9 & 30.0 & 30.0 & 30.0 \\
& Semi-pucca & 12 & 40.0 & 40.0 & 70.0 \\
& Pucca & 8 & 26.7 & 26.7 & 96.7 \\
& 33.00 & 1 & 3.3 & 3.3 & 100.0 \\
& Total & 30 & 100.0 & 100.0 & \\
\hline
\end{tabular}

Source: Calculated From Primary Data

From the table 13 it can be seen that, $30 \%$ respondents have Tin shed house, $40 \%$ respondents have semi-pucca house and about $27 \%$ respondents have pucca house. From these data, it can be seen that, most of the businessmen of this area have financial solvency and for that reason they can bear the semi pucca and pucca house.

Table 14. Number of family member

\begin{tabular}{llllll}
\hline & & Frequency & Percent & Valid Percent & Cumulative Percent \\
\hline Valid & (2-4) people & 3 & 10.0 & 10.0 & 10.0 \\
& (5-7) people & 14 & 46.7 & 46.7 & 56.7 \\
& (8-10) people & 11 & 36.7 & 36.7 & 93.3 \\
& (11-13) people & 1 & 3.3 & 3.3 & 96.7 \\
& Above 14 people & 1 & 3.3 & 3.3 & 100.0 \\
& Total & 30 & 100.0 & 100.0 & \\
\hline
\end{tabular}

Source: Calculated From Primary Data

From table 14 , it can be seen that about $47 \%$ people have family member (5-7), about $37 \%$ people have family member (8-10) and about $3 \%$ people have family member (11-13) or more than 14 people. From these data, it can be seen that, the powerloom business is a labor intensive business and businessmen like to take more children or stay in a join family, rather than in a nuclear family to increase their family member.

Table 15. Changed in food habit after doing business

\begin{tabular}{llllll}
\hline & Frequency & Percent & $\begin{array}{l}\text { Valid } \\
\text { Percent }\end{array}$ & $\begin{array}{l}\text { Cumulative } \\
\text { Percent }\end{array}$ \\
\hline \multirow{2}{*}{ Valid } & Yes & 18 & 60.0 & 60.0 & 60.0 \\
& No & 7 & 23.3 & 23.3 & 83.3 \\
& $\begin{array}{l}\text { No } \\
\text { comment }\end{array}$ & 5 & 16.7 & 16.7 & 100.0 \\
& Total & 30 & 100.0 & 100.0 & \\
\hline
\end{tabular}

Source: Calculated From Primary Data

From table 15 it can be seen that, $60 \%$ respondents said their food habit has changed after doing business, $23 \%$ respondents said their food habit has not changed and about
$17 \%$ respondent did not make any comment. So from this data it can be seen that, most of the respondents can change their financial status by doing this business and that directly contribute to their food habit.

Table 16. Health status

\begin{tabular}{llllll}
\hline & & Frequency & Percent & $\begin{array}{l}\text { Valid } \\
\text { Percent }\end{array}$ & $\begin{array}{l}\text { Cumulative } \\
\text { Percent }\end{array}$ \\
\hline \multirow{4}{*}{ Valid } & Poor & 4 & 13.3 & 13.3 & 13.3 \\
& Medium & 20 & 66.7 & 66.7 & 80.0 \\
& Good & 6 & 20.0 & 20.0 & 100.0 \\
& Total & 30 & 100.0 & 100.0 & \\
\hline
\end{tabular}

Source: Calculated From Primary Data

From table 16 , it can be seen that about $67 \%$ people has medium health, $20 \%$ people have good health, and about $13 \%$ people have poor health. From the above frequency table it can be seen that, $100 \%$ people have accessibility to safe drinking water, about $90 \%$ people have hygienic sanitation facility and $60 \%$ people their food habit has changed after doing this business. All of these directly contribute to improve their health.

Table 17. Kind of change in food habit

\begin{tabular}{llllll}
\hline & & Frequency & Percent & Valid Percent & Cumulative Percent \\
\hline \multirow{3}{*}{ Valid } & Ensure balance diet & 4 & 13.3 & 22.2 & 22.2 \\
& Increase in protein intake & 8 & 26.7 & 44.4 & 66.7 \\
& Increase in both protien,vitamins and minerals intake & 6 & 20.0 & 33.3 & 100.0 \\
& Total & 18 & 60.0 & 100.0 & \\
Missing & System & 12 & 40.0 & & \\
Total & & 30 & 100.0 & & \\
\hline
\end{tabular}

Source: Calculated From Primary Data 
In table 17 it can be seen that, about $13 \%$ respondents said they can ensure their balance diet after doing business, about $27 \%$ respondents said they could increase their protein intake, $20 \%$ respondents said they could increase their protein, vitamins and minerals consumption. $40 \%$ people did not make any comment about their consumption pattern. Many people became solvent after doing this business and for that they can spend more on purchasing meat, chicken, fish and milk which contribute to their protein, vitamins and minerals intake.

Table 18. Socio-economic development after doing business

\begin{tabular}{llllll}
\hline & & Frequency & Percent & Valid Percent & Cumulative Percent \\
\hline \multirow{3}{*}{ Valid } & Yes & 26 & 86.7 & 86.7 & 86.7 \\
& No comment & 4 & 13.3 & 13.3 & 100.0 \\
& Total & 30 & 100.0 & 100.0 \\
\hline
\end{tabular}

Source: Calculated From Primary Data

From table 18 it can be seen that, about $87 \%$ respondent said they can change their socio-economic condition after

doing this business and $13 \%$ respondents did not give any comment.

Table 19. Correlation

\begin{tabular}{|c|c|c|c|c|c|c|c|c|c|}
\hline & $\begin{array}{l}\text { Amount of } \\
\text { investment }\end{array}$ & $\begin{array}{l}\text { No. of } \\
\text { workers }\end{array}$ & $\begin{array}{l}\text { Selling's of } \\
\text { products } \\
\text { per week }\end{array}$ & $\begin{array}{l}\text { Rate of } \\
\text { sale per } \\
\text { cloth }\end{array}$ & $\begin{array}{l}\text { Cost of } \\
\text { production } \\
\text { per cloth }\end{array}$ & $\begin{array}{l}\text { The } \\
\text { amount of } \\
\text { your } \\
\text { financial } \\
\text { help }\end{array}$ & $\begin{array}{l}\text { Educational } \\
\text { status of you }\end{array}$ & $\begin{array}{l}\text { Health } \\
\text { status of } \\
\text { you }\end{array}$ & $\begin{array}{l}\text { Number of } \\
\text { your of your } \\
\text { family } \\
\text { member }\end{array}$ \\
\hline Amount of investment & 1 & .912 & .669 & .588 & .423 & .821 & .265 & .189 & .047 \\
\hline $\begin{array}{l}\text { Pearson Correlation } \\
\text { Sig. (2-tailed) }\end{array}$ & & .000 & .000 & .001 & .020 & .000 & .000 & .317 & .806 \\
\hline $\mathrm{N}$ & 30 & 30 & 30 & 30 & 30 & 19 & 30 & 30 & 30 \\
\hline No. of workers & .912 & 1 & .856 & .555 & .421 & .782 & .161 & -.039 & .283 \\
\hline $\begin{array}{l}\text { Pearson Correlation } \\
\text { Sig. (2-tailed) }\end{array}$ & .000 & . & .000 & .001 & .020 & .000 & .396 & .842 & .129 \\
\hline $\mathrm{N}$ & 30 & 30 & 30 & 30 & 30 & 19 & 30 & 30 & 30 \\
\hline $\begin{array}{l}\text { Selling's of products } \\
\text { per week }\end{array}$ & .669 & .856 & 1 & .416 & .312 & .676 & .031 & --.146 & .438 \\
\hline $\begin{array}{l}\text { Pearson correlation. } \\
\text { Sig. (2-tailed) }\end{array}$ & 000 & 000 & .000 & .022 & .094 & .001 & .871 & .443 & .016 \\
\hline $\mathrm{N}$ & 30 & 30 & 30 & 30 & 30 & 19 & 30 & 30 & 30 \\
\hline $\begin{array}{l}\text { Rate of sale per cloth } \\
\text { Pearson }\end{array}$ & .588 & .555 & .416 & 1 & .915 & .603 & .099 & .015 & .102 \\
\hline $\begin{array}{l}\text { Correlation Sig. (2- } \\
\text { tailed) }\end{array}$ & .001 & .001 & .022 & . & .000 & .006 & .603 & .939 & .591 \\
\hline $\mathrm{N}$ & 30 & 30 & 30 & 30 & 30 & 19 & 30 & 30 & 30 \\
\hline $\begin{array}{l}\text { Cost of production per } \\
\text { cloth }\end{array}$ & .423 & .421 & .312 & .915 & 1 & .516 & .054 & -.064 & .117 \\
\hline $\begin{array}{l}\text { Pearson Correlation } \\
\text { Sig. (2-tailed) }\end{array}$ & .020 & .020 & .094 & .000 & . & .024 & .777 & .735 & .539 \\
\hline $\mathrm{N}$ & 30 & 30 & 30 & 30 & 30 & 19 & 30 & 30 & 30 \\
\hline $\begin{array}{l}\text { The amount of your } \\
\text { financial help }\end{array}$ & .821 & .782 & .676 & .603 & .516 & 1 & -.122 & .178 & .570 \\
\hline $\begin{array}{l}\text { Pearson Correlation } \\
\text { Sig. (2-tailed) }\end{array}$ & .000 & .000 & .001 & .006 & .024 & & .620 & .465 & .011 \\
\hline $\mathrm{N}$ & 30 & 19 & 19 & 19 & 19 & 19 & 19 & 19 & 19 \\
\hline $\begin{array}{l}\text { Educational status of } \\
\text { you }\end{array}$ & .265 & .161 & .031 & .099 & .054 & -.122 & 1 & .387 & -.284 \\
\hline $\begin{array}{l}\text { Pearson Correlation } \\
\text { Sig. (2-tailed) }\end{array}$ & .157 & .396 & .871 & .602 & .777 & .620 & & .035 & .128 \\
\hline $\mathrm{N}$ & 30 & 30 & 30 & 30 & 30 & 19 & 30 & 19 & 30 \\
\hline Health status of you & .189 & -.038 & -.146 & .015 & -.064 & .178 & .387 & 1 & -.197 \\
\hline $\begin{array}{l}\text { Pearson Correlation } \\
\text { Sig. (2-tailed) }\end{array}$ & .317 & .842 & .443 & .939 & .735 & .465 & .035 & & .296 \\
\hline $\mathrm{N}$ & 30 & 30 & 30 & 30 & 30 & 19 & 30 & 30 & 30 \\
\hline $\begin{array}{l}\text { Number of your } \\
\text { family member }\end{array}$ & .047 & .283 & .438 & .102 & .117 & .570 & -.284 & -.197 & 1 \\
\hline $\begin{array}{l}\text { Pearson Correlation } \\
\text { Sig. (2-tailed) }\end{array}$ & .806 & .129 & .016 & .591 & .539 & .011 & .128 & .296 & \\
\hline $\mathrm{N}$ & 30 & 30 & 30 & 30 & 30 & 19 & 30 & 30 & 30 \\
\hline
\end{tabular}

Source: Calculated From Primary Data; * Correlation is significant at the 0.05 level (2-tailed). ** Correlation is significant at the 0.01 level (2-tailed). 
$>$ From table 19 it can be seen that amount of investment and no. of workers are highly positively correlated. That's means if the amount of investment increases, then the number of workers will also increase.

$>$ Amount of investment also positively correlated with selling's of product per week. Because when investment increases, the number of production of cloths also increases and leads to higher selling's per week.

$>$ Amount of investment is positively correlated with rate of sale per Lungi. Because, when businessmen invest more, then they can go for direct packaging and marketing and can charge higher price for their product.

$>$ The amount of investment is positively correlated with the amount of financial help. Because when businessmen invest more, they take more financial help.

$>\quad$ The number of workers and selling's of products per week are also are also positively correlated. When no. of workers increases they can make more Lungi and thus selling's per week increase.

$>\quad$ The number of workers and rate of sale per Lungi are positively correlated. Because more workers are needed when businessmen go for packaging and direct selling's and they can get more price for their Lungi.

$>\quad$ The number of workers and the amount of financial help is also highly positively correlated. Because more workers need more investment requires more financial help.

$>$ Cost of production per Lungi and rate of sale per Lungi are directly highly correlated. Because when cost of production increase, automatically rate of sale per Lungi also increase.

$>$ Rate of sale per cloth and the financial help are directly positively correlated. Because when businessmen try to increase their rate of sale per Lungi, they need to do more processing and which requires higher investment which leads to financial help.

$>$ Cost of production and amount of financial help are directly correlated. When cost of production increase, businessmen need more financial help.

\subsection{Regression Analysis}

Table 20. Model Summary

\begin{tabular}{lllll}
\hline Model & R & R Square & $\begin{array}{l}\text { Adjusted R } \\
\text { Square }\end{array}$ & $\begin{array}{l}\text { Std. Error of } \\
\text { the Estimate }\end{array}$ \\
\hline 1 & .917 (a) & .841 & .714 & .24531 \\
\hline
\end{tabular}

Source: SPSS Regression result of the field work; a Predictors: (Constant), Collect inputs, Cost of production per cloth, Sellings of products per week, Working hours covered by using generator, Amount of investment, The amount of the financial help, Rate of sale per cloth, No. of workers

Table 21. Anova(b)

\begin{tabular}{lllllll}
\hline Model & & $\begin{array}{l}\text { Sum of } \\
\text { Squares }\end{array}$ & df & $\begin{array}{l}\text { Mean } \\
\text { Square }\end{array}$ & F & Sig. \\
\hline 1 & Regression & 3.188 & 8 & .398 & 6.622 & $.004(\mathrm{a})$ \\
& Residual & .602 & 10 & .060 & & \\
& Total & 3.789 & 18 & & & \\
\hline
\end{tabular}

Source: Calculated From Primary Data; a Predictors: (Constant), Collect inputs, Cost of production per cloth, Sellings of products per week, Working hours you cover by using generator, Amount of investmen, The amount of your financial help, Rate of sale per cloth, No. of workers; b Dependent Variable: Economic development after doing business

Table 22. Coefficients(a)

\begin{tabular}{|c|c|c|c|c|c|c|}
\hline \multicolumn{2}{|c|}{ Model } & \multicolumn{2}{|c|}{ Unstandardized Coefficients } & \multirow{2}{*}{$\begin{array}{l}\text { Standardized Coefficients } \\
\text { Beta }\end{array}$} & \multirow[t]{2}{*}{$\mathbf{T}$} & \multirow[t]{2}{*}{ Sig. } \\
\hline & & B & Std. Error & & & \\
\hline \multirow[t]{9}{*}{1} & (Constant) & 1.368 & .303 & & 4.511 & .001 \\
\hline & Amount of investment & -.087 & .145 & -.249 & -.600 & .562 \\
\hline & No. of workers & .654 & .245 & 1.904 & 2.668 & .024 \\
\hline & Cost of production per cloth & -.126 & .130 & -.307 & -.974 & .353 \\
\hline & Sellings of products per week & -.463 & .144 & -1.421 & -3.210 & .009 \\
\hline & Rate of sale per cloth & .076 & .166 & .175 & .457 & .657 \\
\hline & The amount of your financial help & -.029 & .101 & -.088 & -.287 & .780 \\
\hline & Working hours you cover by using generator & .330 & .159 & .581 & 2.076 & .065 \\
\hline & Collect inputs & -.752 & .161 & -.841 & -4.668 & .001 \\
\hline
\end{tabular}

Source: Calculated From Primary Data; a. Predictors: (Constant), Collect inputs, Cost of production per cloth, Selling's of products per week, Working hours covered by using generator, Amount of investment ,The amount of the financial help, Rate of sale per cloth, No. of workers.; b. Dependent Variable: Economic development after doing business

From this regression analysis, it was found that the value of $\mathrm{R}$ square is 0.841 . That means, this data cover about 84 percent of research area and the regression value is statistically highly significant. It is concluded that, no. of workers, selling of products per week and collection of inputs have statistically significant (significance value is less than 0.01 and 0.05 ) effect on economic development after doing business. Moreover no. of workers, rate of sale per cloth and working hours covered by using generator are positively associated with economic development after 
doing business. Because beta value represents the slope means nature (positive/negative) of relationship. On the other hand, amount of investment, cost of production per cloth, selling of products per week, the amount of financial help and collection of inputs are negatively associated with the economic development after doing business.

\section{Future Prospect of Business}

This industry is related with many diversified activities. The flourishing powerloom business will directly contribute to expand many other business and profession. The following business and profession have a great prospect in the locality for expansion of power loom business.

1. Loom making: This is a new profession in this area. The need for this profession arises with the expansion of powerloom business in this area.

2.The powerloom business is related with many inputs like Yarn, Dyne, Yarn beam, Inner shuttle, Beam cover, Shana bow etc. To meet up the demand for these inputs many people involved themselves with buying and selling of these materials after expansion of powerloom business in the selected area. This business will expand more in the future with the expansion of powerloom business.

3. Many workshops already established in this area and many will be established with the expansion of powerloom business in the area.

4. There is a great prospect of electrical equipment shops business in this area, because powerloom business is totally dependent on electricity.

5. In the entire powerpoom industry women are involved in various stages of work, such as reeling Bobbin, cutting loose threads and doing block design on ready-made sarees. However, women are now working as weaver, designer and entrepreneur. Women are main consumers of saree, women can also be involved in a large number in different sectors of the production, which may help in revival of the industry. As women are creative by nature and they can understand the taste of the consumers better, so if they are given necessary professional training on designing they can be involved in this sector.. Women's honesty, managing quality and capacity for good interaction with consumer will help them to work as a good entrepreneur. This opportunity will help them to support their family more financially. Especially the female-headed family will be highly benefited. It will also create the scope of engaging a large number of women as worker under a women entrepreneur. Thus more involvement of women will be ensured in the powerloom industry and women empowerment will also be promoted.

6. There is a great prospect of social infrastructural development in these localities with the expansion of this business. Society will develop in all aspects like in literacy rate, health facilities, transportation and communication facilities, standard of living etc with pace of time for doing this business.

\section{Problems of this Business}

1. Problems of electricity: The first and foremost problem of this business is the scarcity of electricity. This business is totally dependent on electricity. Everyday businessmen have to face 3-4 hours load shedding in their working period. To continue their work in these periods, businessmen use generator machine which increase their production cost by a great extent.

2. Unhealthy working condition : The powerloom machines create a very high decibel sound when they are operated .The noise is so strong that it is very difficult for a worker to hear his own voice at the time of working. This noisy environment create serious health hazards for workers like hearing problem, insomnia, sinus problem etc

3. Marketing problem: The businessmen of the powerloom industry are not aware about the management skills in the area of marketing. They are mostly dependent on the middlemen. The businessmen face not only marketing problem but they are exploited by the middlemen

4. High cost of raw materials: . Shortage of raw material is also a hurdle for the powerloom industry. The shortage of raw material takes place because of two main reasons. When the export of cotton rises and another is artificial shortage by the yarn merchants/ commission agents.

5. Decreasing demand of production: Open market policy pursued by the Government has opened the country to Indian sarees and Longi. Indian sarees and Lungi for their cheaper prices, varied designs \& availability usually lure more local buyers. So gradually the sale is declining.

6. Lack of variation in design: The design of Lungi and sarees are almost traditional. The local designers do not have any institutional training and have no interaction with professional designers. So lack of variation in design is one of the causes of decreasing demand.

7. Lack of Govt. policy: The Govt. has no adequate policy about this business. For lack of policy businessmen of this industry cannot go for purchasing their raw materials directly from foreign country and also exporting their products. For that they have to pay more for their raw materials and their production cost increase.

8. Lack of modern technology: The industry is running discarded and obsolete powerlooms. In Sirajgonj about 99\% powerlooms are obsolete and outdated, which results in low productivity; cost of maintenance is high \& production of low quality fabrics.

9. Small scale investment: The majority of the powerloom units are mostly small units. They run their business with small investment. Because of small scale they are not in a position to upgrade \& modernize their units.

10. Lack of infrastructural facility: The infrastructural facilities are not well developed. There is no sufficient infrastructure like road ways, truck of the growth of the powerloom industry. 
11. Lack of processing Facilities: The major product of the powerloom industry is grey cloth which is semi finished. Many businessmen sell it without processing, so they can not enjoy the main profit.

12. Lack of technical Training: The workers employed in powerloom industry are mostly technically untrained. They acquire the skills through experience. Because of nontechnical training their productivity is affected.

\section{Conclusion}

The importance of the textile industry in the economy of Bangladesh is very high. Furthermore, the industry is expected to be the catalyst in the industrialization of Bangladesh, and has been declared as a thrust sector by the government. The powerloom industry is largely household based, carried out with labor contributed by entire family. The industry exhibits considerable diversity in terms of products, organizational base, as well as in relation between actors within the production structure. This industry provided individuals with gainful employment and was seen as a means of ensuring self- sufficiency and survival of the country's traditional crafts and artistry. This sector has a great potentiality to meet substantial requirements of fabrics in the export orientated garment industry. All recommendations are to boost up the sales and market share of powerloom industry in Bangladesh. This industry is facing a lot of problems that have been highlighted through our discussion and made necessary recommendations to bring the powerloom industry at the blooming stage of development. It should be extended the helping hand to the government and NGOs to pave the way of development for our poor weavers.However, over the course of my Project investigations, It has been realized that Bangladesh's low labor cost, skill development potential, a presently expanding market, and favorable conversion cost can be used to turn the challenges of the quota-free market into a window of opportunity. industry and investing in other sectors, thus creating a vacuum in the market.

\section{Recommendations}

1. Establish a favorable policy to flourish this industry.

2. Keep the input price to a minimum level.

3. Up gradation \& Modernization of existing technology.

4. Up gradation of Plain powerlooms to Semi-Automatic level

5. Establish Industrial Estate \& Textile Park

6. Marketing Complexes: The government should develop and encourage the Textile Marketing Complexes in which the government should control the pricing policies.

7. Improve processing Facilities
8. Ensure the continuous supply of electricity.

9. Provide technical training to the both businessmen and workers the powerloom workers.

10. Financial Institution: Adequate, timely and cheap financial facilities should be provided by the financial institutions. On the lines,special financial institution for textile sector should be formed for the financial help of the secto

11. Census of Powerloom Industry: Census of the powerloom industry should be conducted after every five years in which basic statistics of their needs, raw material, growth etc. should be conducted. It will be more effective for the programming and implementation of schemes.

12. Co-operative Organization: The co-operative form of organisation should be strengthened and the government should actively participate in the promotion of Powerloom Co-operative Societies.

13. Provide trademark to the businessmen for their innovation and identification of its product.

14. Government should take necessary steps to ensure infrastructure development of the working place of powerloom workers, such as water supply, electricity supply, drainage and sanitary facilities, road constructions etc.

\section{References}

[1] Arif Anjum and D. V. Thakor. An Analytical Study of the Functioning and the Problems of the Powerloom Industry in Maharashtra with Special .Reference to Malegaon Dist. Nashik. International Journal of Trade, Economics and Finance, Vol. 2, No. 3, June 2011

[2] Golam Mostafa Jibon, Hard Times, The independent, Sunday, $5^{\text {th }}$ January, 2014.

[3] Md. Shahriar Akter, Suntu Kumar Ghosh, HANDLOOM INDUSTRY ON THE WAY OF EXTINCTION: AN EMPIRICAL STUDY OVER THE PRE- DOMINANT FACTORS. BRAC University Journal, Vol. II, No. 2, 2005, pp. 1-12

[4] N. M. Rahmatullah1*, Rokeya Begum2, Kamrun Nahar3 and Rehana Sultana4. Effect of Microcredit on Handloom Weavers of Grameen-Check Producers of Sirajganj District of Bangladesh: A Case Study in Six Selected Villages. Journal of Experimental Sciences Vol. 1, Issue 4, Pages 21$26[2010]$

[5] S. Manikandan· ,Dr. S. Thirunuvakkarsu, TAMIL NADU POWERLOOM INDUSTRY ISSUES \& CHALLENGES (A CRITICAL STUDY, International Research Journal, July 2010 ISSN- 0975-3486 RNI: RAJBIL 2009/30097 VOL I *ISSUE 10

[6] Uttam Paul, A study of socio economic status of workers in the unorganized powerloom sector of West BengalGlobal Advanced Research Journal of Agricultural Science (ISSN: 2315-5094) Vol. 2(2) pp. 065-073, February, 2013. 